\title{
Joanna Księska-Koszałka
}

The John Paul II Catholic University of Lublin

\section{Paul Hindemith and the Idea of Progress, Tradition and Neoclassicism}

\section{Abstract}

Paul Hindemith is one of the most famous composers of the 2oth century as well as the most important thinkers in the field of music. His aesthetic beliefs are mainly inspired by Boethius and Saint Augustine. He raises an issue of ideas of tradition and progress, which seemed quite disputable in the music of the 2oth century. Hindemith believes that some universal spiritual principles exist in the world, which must be integrated by composers in the process of creating music. $\mathrm{He}$ criticises the approaches in which the technique itself appears to be predominant, therefore he negates such techniques as the twelve-tone chromatic scale. In the Hindemith's view, the development of music must be based on traditional fundaments, which, however, can be linked to modern styles and ideas. That seems crucial not only in the process of composing, but also in teaching music, both in theory and in practice. 


\section{Keywords}

Paul Hindemith, idea of progress, Neoclassicism, aesthetics

Paul Hindemith is one of the most colourful personas of the musical environment of the 2oth century. Beside his rich compositional output, he also left original aesthetic views that are a rarely discussed issue in the field of Polish musicology. Meanwhile, this reflection influenced strongly the shape of his compositions that belong to the Neoclassical style, predominating in his art. The aim of this article is to present the Hindemith's view on the subject of tradition and progress in music in the perspective of his epoch and to indicate the examples of realization of this thought in the several areas of the creative activity of the composer.

\section{Between Tradition and Modernity-Aesthetic Disputes in the 2oth Century}

\footnotetext{
Music of our century wears two hats. On the one hand, it is open-as never before-for the future, sensible for extreme novelty. From the other-also as never before-it comes back to the past, recognizing its rooting in the history. ${ }^{1}$
}

This is how Bohdan Pociej starts his paper concerning music of the past century. Looking at the 2oth-century music, one could have an impression that the author's words accurately show this fission that is mirrored by the abundance of aesthetics and artistic attitudes, the variety of styles and tendencies. Frequently, there are huge differences between them, but very often they can be summarized as a position of a given issue in the continuum tradition-progress.

Most frequently, the discussions and arguments were undertaken in the perspective of this 2oth-century aesthetic reflection about music.

\footnotetext{
B. Pociej, Co się stało z muzykq w naszym stuleciu?, "Ethos" 1997, No. 4, p. 21.
} 
These disputes often appeared in a form of severe criticism, and brutal words were used by the followers of both sides. The problem of tonality and dodecaphony was, certainly, the branch of a discussion around the idea of tradition and progress.

Among these who were openly against the tradition and approved the idea of progress was Theodor Wiesengrund Adorno. He presented his beliefs in the work Philosophy of New Music (1949), which he divided into two parts: Schönberg and Progress and Stravinsky and Reaction. ${ }^{2}$ As he was under the influence of the liberal and Marxist thought, Adorno claimed that the only way to survive in the capitalist society is to stand against it. ${ }^{3}$ Because of that, the aim of music in his view is to destroy the order and to introduce chaos, and it should be done through negation of all conventions and traditional structures. This ideal is realized by the above-mentioned dodecaphony-according to the German philosopher, the only form of radical music that can be called authentic, ${ }^{4}$ because it is the only one that has the force of progress in itself. ${ }^{5}$

According to Adorno, at the opposite side to the idea of progress stands Igor Stravinsky's music, that is assessed by him as the example of conformism and backwardness. Negating the whole compositional output of the composer, Adorno expresses his strong criticism towards Stravinsky. He perceives the particular elements of the composer's style as the symptoms of serious mental disorders. Stravinsky-in Adorno's viewpoint-has a psychopathic features, symptoms of depersonalization, obsessive-compulsive disorder, schizophrenia etc. ${ }^{6}$ In the text, it is visible how radically Adorno negates any signs of respect for the tradition.

The opposition of tradition and progress can be also found in the works by numerous other theorists. Hans Stuckenschmidt distinguishes

\footnotetext{
T.W. Adorno, Philosophy of New Music, transl. by R. Hullot-Kentor, MinneapolisSaint Paul 2006.

3 S.Jarociński,ZdziejówmyśliomuzyceXX wieku. Theodor WiesengrundAdorno, "Muzyka" 1971, No. 4, p. 35.

4 E. Fubini, Historia estetyki muzycznej, transl. into Polish by Z. Skowron, Kraków 1997, p. 438.

5 A. Jarzębska, Spór o piękno muzyki. Wprowadzenie do kultury muzycznej XX wieku, Wrocław 2004, p. 196.

$6 \quad$ Ibid., pp. 192-196.
} 
two trends, analysierende and restituirende. ${ }^{7}$ On the other hand, Arnold Cassela describes Arnold Schönberg's style as dekadent und atonal, and Igor Stravinsky's-reaktionär und diatonisch. ${ }^{8}$

What is connected with the idea of progress is the term "new music" that has commonly been used thanks to Paul Bekker's lecture Neue Musik, given in 1919. There, for the first time in the field of music, the consciousness of the modernity, a triumph of youth, explosion, breakthrough and the beginning of a new epoch was raised. Obviously, this term was associated with the Schönberg's school. ${ }^{9}$

On the contrary, the affection and respect for tradition of stylistic continuity appeared in Neoclassicism. However, it should be noticed that this term is not precisely defined in contemporary musicological literature. Its definition has several methodological difficulties. It has not been decided if the term concerns the period in history of music, a trend, school, or style-the researchers' opinions are not easy to conciliate in this aspect. ${ }^{10}$ In musicological literature, there is the inclination to define Neoclassicism as a trend in the music of the 2oth century (or the aesthetic orientation), which characteristic feature is a reference to forms and techniques of earlier music and creating the new musical style on that base. Fred Prieberg claims that Neoclassicism aimed at the synthesis of old stylistic techniques and artistic forms with new thoughts-not picturing the past, but rather creating a strong base for the present. ${ }^{11}$ The artistic program of Neoclassicism was shaped in opposition to Romanticism, Impressionism and Expressionism. Its prerequisites are most frequently present in treating music as an autonomic art, in underlining the role of knowledge, intellect, and craft in the process of composing, as well as in return to Classical balance between emotional and constructive factors. ${ }^{12}$

7 Compare: Z. Helman, Neoklasycyzm w muzyce polskiej XX wieku, Kraków 1985, p. 216.

I Ibid.

9 C. Dahlhaus, H.H. Eggebrecht, Co to jest muzyka?, transl. into Polish by D. Lachowska, Warszawa 1992, p. 99.

10 Z. Helman, op. cit., p. 7.

11 Compare: ibid., p. 12.

12 Ibid., p. 16. 
The composers who are connected with Neoclassicism are, beside Hindemith, also Igor Stravinsky, Erik Satie, Sergey Prokofiev, Albert Roussell, composers of Les Six, Maurice Ravel or Béla Bartók. ${ }^{13}$

\section{Origin of Hindemith's Aesthetic Views}

Although Hindemith is traditionally perceived as a representative of Neoclassicism, mainly due to his famous slogan Zurück zu Bach, at the beginning of his compositional activity he belonged to avant-garde and he had radical, anti-Romantic tendencies, inclination towards dissonance and wanted to achieve the effect of surprise and shock on the audience. Some of his early works, associated with Expressionism, were considered as scandalous. The opposition against Romantic tendencies was one of the elements of fascination by the postulates of so-called The New Objectivity (Neue Sachlichkeit); in accordance with it, music should come closer to everyday reality, a life of an ordinary person, as well as relate to social issues. Resignation from Romantic luxury and pathos in order to paint a lucid picture of reality and achieve consequent realism should be, according to the proponents of this idea, the aim of the artist's activity. ${ }^{14}$

Romanticism and all the elements of sophisticated aesthetics are put in opposition to the aesthetics of so-called Gebrauchsmusik, which also played an important role in Hindemith's art. New Gebrauchsmusik (utility music) was thought to be created for wider publicity, also for non-professionals and amateurs. It resigned from the excessive complication and sophisticated compositional techniques and aimed at making the means of expression easier. ${ }^{15}$

Beside the innovative tendencies in Hindemith's art, Neoclassical trend became present. It became more visible as he was more mature as a composer, teacher and music theorist. In his compositions, Neoclassical tendencies could be noticed since the 1920s, and remained in the composer's style until the end of his life. The characteristic features of Neoclassical

13 Compare: M. Piotrowska, Neoklasycyzm w muzyce XX wieku, Warszawa 1982, p. 14.

14 Compare: N. Grosch, Die Musik der Neuen Sachlichkeit, Stuttgart-Weimar 1999.

15 A. Jarzębska, op. cit., pp. 154-158. 
pieces, especially in the late period of his activity, were deep non-musical content, referring to the worldview, religion and philosophy, including aesthetic philosophy. Numerous works also have allusions to the political and social situation of that time, which, having influence on the composer's life, were present in his compositions as well. ${ }^{16}$

A crystallization of the Hindemith's aesthetic views was a process that was happening simultaneously with the changes of his compositional work over the years. Several aspects of music aesthetics can be found in prefaces to his compositions, his diary, some lectures, speeches and letters. Some aesthetic principles were presented by him in the 1940 o in the first part of the coursebook Unterweisung im Tonsatz, in which he described the theoretical system of the composer, based on these prerequisites. The detailed picture of Hindemith's beliefs is presented in the book entitled A Composer's World, consisting of a cycle of lectures given at the Harvard University at the break of 1949 and 1950. Ten years later, the German wider edition of it was published, entitled Komponist in seiner Welt. Weiten und Grenzen.

The main inspirations of Hindemith's aesthetic thought were Boethius's and Saint Augustine's papers concerning music. Hindemith's beliefs on, among others, nature and perception of music, harmony of a creative act, are rooted in them. Beside mentioned thinkers, Hindemith refers to other representatives of philosophy of the Ancient Times and the Middle Ages. He also refers to, although less significantly, the thoughts of Cassiodorus, Plato (political functions of music) and one of the sceptics, Sextus (the attitude toward music). Among the philosophers of the early modern period, he had respect for Johannes Kepler as an author of original conception of harmony of spheres. ${ }^{17}$

Hindemith is one of the few 2oth-century thinkers, whose beliefs are rooted in such distant past. He also belongs to the artists who wanted to revive the best achievements of the past and integrate

16 Life and art of Hindemith is wider discussed by Giselher Schubert in a perfect biography of the composer. See: G. Schubert, Paul Hindemith, Hamburg 1981.

17 Compare: P. Hindemith, Komponist in seiner Welt. Weiten und Grenzen, Zurich 1959, pp. 17-29. 
them in the new techniques, stylistics and culture. He understands Neoclassicism and realises its prerequisites in the specific way. Due to those aspects, he speaks extremely emotionally on the topic of ideas concerning tradition and progress, and his texts make an important contribution to the debates about the way in which music should develop, that was present during the whole 20 th century.

\section{Understanding of Tradition and Progress. Manifestations of Neoclassicism in Hindemith's Music}

In the definition of Neoclassicism that was cited before, the term refers, among others, to the direction in art and aesthetic orientation. In the case of Hindemith, both possibilities are justified. What is more, there is no doubt that his attitude, marked by the deep respect for tradition, is reflected not only in his compositions, but also in other areas of his musical activity. For Hindemith, the past is a great source of inspiration in the philosophical field, on the basis of theoretical and pedagogical work, as well as in performance practice. Connections of these spheres will form the basis for consideration in further part of this paper.

As I have mentioned above, the roots of Hindemith's aesthetic views can be found in the aesthetics of St. Augustine and Boethius. The composer mentions their point of view when analyzing almost every issue discussed in Komponist in seiner Welt. Unterweisung im Tonsatz and numerous lectures also contain many references to their philosophy. How important is this context for Hindemith can be seen in the book Aufsätze, Vorträge, Reden, edited by Giselher Schubert, which consists of Hindemith's speeches and lectures on various topics, mainly in the field of music aesthetics. The arguments presented there are often supported by quotations from the works of St. Augustine and Boethius. Moreover, even critical texts presented in this work that concern the topic of the musical life of that time, are formed consequently based on the ideas of St. Augustine and Boethius, and frequently refer to the facts from epochs in history of music. For example, one of his lectures is focused on the status of Boethius's musica mundana, mu- 
sica humana and musica instrumentalis in the contemporary world. ${ }^{18}$ In another lecture, the assessment of the musicians' attitude is made by the composer based on the belief quid est musicus (English: "who is a musician?") by Boethius. ${ }^{19}$ In lectures and speeches concerning the topic of musical material, he refers widely to the antique and early modern period's theoretical treatises.

These historical texts were a source of never-ending inspiration for Hindemith. They prompted him to think, study and experiment, provide arguments and examples. Based on them, the book Komponist in seiner Welt was written and the theoretical system of the composer was published. Generally speaking, the Hindemith's theoretical writings are a perfect example of creating "new" based on the synthesis of "old". Hindemith's universalism is particularly evident in Unterweisung im Tonsatz, above all in the context of perception by its tonality and music in general. Both of these areas are, in his view, a reflection of the laws of nature and mirror the rules governing the entire universe, although these theories are read and re-interpreted by the theorist, creating the frames for the original theoretical system. ${ }^{20}$

Hindemith definitely isolates himself from looking at the development of music as a process which is predominating as a result of sudden changes and revolutions. The idea of progress, as understood by Adorno, presumes destruction and negation of the old order, and is unacceptable for Hindemith because it violates rules. Therefore, the author of Komponist in seiner Welt more than once makes critical statements about the topic of the activity of those theorists and composers who, devoted to the falsely understood idea of progress, do everything to create something new. However, it does not mean that the idea itself is disapproved by Hindemith. But, as he underlines, it cannot be the aim in itself, the aim of obsessive aspirations. It leads to the situation in which music is not crucial anymore, and only progress

18 Compare: P. Hindemith, Betrachtungen zur heutigen Musik, [in:] idem, Aufsätze, Vorträge, Reden, ed. G. Schubert, Zurich 1994, pp. 131-176.

19 P. Hindemith, Musik Und Musiker in alter und neuer Zeit, [in:] idem, Aufsätze, op. cit., pp. 187-202.

20 P. Hindemith, Unterweisung im Tonsatz, vol. 1, Theoretischer Teil. Erweiterte Auflage, Mainz 1940. 
means something. As a result, it is unacceptable for Hindemith to work in a way that a composer, when meets some elements of tradition, consciously negates them and avoids them, what-according to him-is especially visible in the field of harmony. He claims that such technique has nothing in common with creating-it is rather a destruction, leading to the total chaos. ${ }^{21}$ This thought is the greatest accusation of Hindemith towards his contemporary artists.

The composer pays special attention to the fact that in contemporary music, in principle, no importance is given to anything other than technique. For him it is a negation of the principle of all music and the purpose of its existence:

\begin{abstract}
What is the composer talking about today, what are the basic issues that bother him? Atonality, twelve-tone technique, functional music, orchestration, formal problems-technique, nothing more than a technique; and what technique! Not the one that is to serve spiritual purposes in the highest perfection-no, technique as the aim in itself, juxtaposition of sounds as the content of life, evaluation of consonances as a worldview, mixing timbres as a sectarian substitute for religion, inversion of subjects and works as a passion-it is all that the composer feels today. [...] Are there still composers who want to exceed everything and tell us without hesitation what a steadfast spiritual principle dictates them? Who wants to tell us in pure language by what deeper thoughts are they inspired? ${ }^{22}$
\end{abstract}

As it is well-known, Hindemith had a huge respect for the fluency in operating the musical material; for him, it was always a necessary

${ }^{21}$ Ibid., pp. 168-176.

22 "Und wovon spricht heute ein Komponist, was sind die Hauptfragen, die ihn bedrängen? Atonalität, Zwölfentontechnik, Gebrauchsmusik, Orchesterbehandlung, Formprobleme-Technik, nichts als Technik; und was für eine Technik! Nicht etwa eine, die in möglichster Vollkommenheit einem spirituellen Zwecke zu dienen hätte-nein, die Technik als Selbstzweck, die Tonzusammenstellungen als Lebensinhalt, die Beurteilung von Klängen als Weltanschauung, die Inversion von Themen und Stücken als Leidenschaft-das ist's, was den Komponisten heute erfüllt. [...] Haben wir keine Komponisten mehr, die das alles überwunden haben und uns sagen, was ihnen in glücklichen Augenblick ein unfaßbares geistiges Prinzip diktierte? Die uns in einer reinen Sprache fühlen lassen, welch hohe Gedanken sie bewegen? ", ibid., p. 175. 
condition to compose-but never a sufficient one. According to him, music should primarily serve people through expressing higher truths and ideals. Hindemith himself always tried to compose his pieces in a way that would meet both these conditions-technical and spiritual perfection-because it was what Augustinian and Boethian tradition told him.

In his music, Hindemith thus combines the Neoclassical ideals in music with the subject of the deepest human truths and values, to which undoubtedly belongs the tradition and legacy of the past. Hence, he rejects the idea of progress in music, understood as the continuous achievement of ever higher degrees of development and increasing complexity of technique. He is rather inclined to see the historical development in the form of a spiral, showing the eternal renewal of a tradition at its subsequent levels. He believes that in every moment in history, the same laws must be in force, on which music has always been based. ${ }^{23}$ Because of that, in his art he uses Gregorian and Protestant chant, folk song, fauxbourdon, rhetoric and number symbolism. He takes Renaissance forms-madrigal and motet, Baroque homophony and polyphony, Classical Italian opera, concerto and symphony. Indeed rarely, but he also refers to Romanticism, which is inspiring for him because of its expression. Despite the source of inspiration, he links the heritage of the history with modern musical language and uses modern technical solutions.

The greatest inspiration for Hindemith in the process of composition was always the Baroque era and works of Johann Sebastian Bach. He regards Bach as the greatest composer in the history of music, who left behind the legacy of a superhuman kind (übermenschlicher Art). Hindemith claims that Bach was a personification of the ideal creator in the Augustian and Boethian sense. Therefore, he calls for studying Bach's output, but not only-also the composer's personality, methods of his work and ideas that guided him are equally important. According to Hindemith, if we look at the Leipzig cantor, we will never lose sight of the highest goals of music, and we will never understand trivial, careless and meaningless music. ${ }^{24}$

23 Ibid., pp. 175-176.

24 P. Hindemith, Johann Sebastian Bach. Ein verpflichtendes Erbe, Frankfurt 1957, p. 41. 
It is clearly visible, therefore, that Hindemith treated tradition as a powerful element of education, a role model, a legacy that deserves deep respect and attention. Hence, also in his pedagogical work he used the ideals of the past. He not only gave his students knowledge of the issues of composition, history and theory of music. He also showed them how to put it into practice and combine tradition with the spirit of modernity. Therefore, he required from the students not only the knowledge of shaping the musical material and the ability to use it. He drew attention to the importance of knowledge of all issues related to music-knowledge of instruments, history, theory of music, aesthetics, psychology, philosophy, mathematics and acoustics. In his lectures, he combined these issues with the reality of work of a contemporary composer-the conditions concerning the places where music is performed, the performance possibilities of contemporary instruments and orchestras, musical education. He also did not avoid discussion about financial matters.

Also, when it comes to the performance practice, history is-as in the antique aphorism - the teacher of life for Hindemith. Because of that, he focuses on the performance compatible with the sounding characteristic for the given epoch. He is also interested in old instruments, what can be perfectly illustrated by his great fascination by viola d'amore. ${ }^{25}$

What is important, Hindemith opposes brilliant virtuosity, if it is not meant for the rest of the musical performance, but it is an aim in itself. In this case, the composer, in the Boethian spirit, rejects it as a manifestation of the artisan's-not the real artist's-activity. For this reason, he criticizes the music education at his time, which in his opinion is a factory of performers, who, according to Boethius's quid est musicus concept, should not be considered as musicians. Hindemith even states that musical education, which emphasizes the achievement of increasing technical proficiency, neglects or omits other issues of musical practice, should not have a reason to exist. ${ }^{26}$

25 P. Hindemith, Über die Viola d’amore, [in:] idem, Aufsätze, op. cit., pp. 125-130.

26 P. Hindemith, Musik und Musiker in alter und neuer Zeit, [in:] idem, Aufsätze, op. cit., pp. 187-202. 


\section{Conclusion}

Hindemith's Neoclassicism is almost omnipresent in his compositional activity, but not only there. Tradition leaves its trace and is a source of wisdom and inspiration in all fields of his musical activity: practice, theory, journalism and education. However, despite his clear inclinations toward conservatism, Hindemith continuously crosses this tradition. Genres and musical forms of the past are treated by him originally and gain a new aspect and, thanks to that, they preserve its identity, achieving the further levels of development at the same time. Harmony, although it is based on the tonality, gets a new dimension, and sounding of music-totally new characteristics. With help of arguments from the history, education and performance practice do not confined themselves to what is old, but also absorb new elements. In every area of his activity, this composer experiments and uses the newest technical solutions.

Hindemith should be therefore located in the history at the crossroad of two words-the old one, that contains eternal, fundamental, unbreakable laws and values, and the new one, which is not afraid of challenges, to take what is old and to develop it.

\section{Bibliography}

Adorno T.W., Philosophy of New Music, transl. by R. Hullot-Kentor, Minneapolis-Saint Paul 2006.

Dahlhaus C., Eggebrecht H.H., Co to jest muzyka?, transl. into Polish by D. Lachowska, Warszawa 1992.

Fubini E., Historia estetyki muzycznej, transl. into Polish by Z. Skowron, Kraków 1997.

Grosch N., Die Musik der Neuen Sachlichkeit, Stuttgart-Weimar 1999. Helman Z., Neoklasycyzm w muzyce polskiej XX wieku, Kraków 1985. Hindemith P., Betrachtungen zur heutigen Musik, [in:] idem, Aufsätze, Vorträge, Reden, ed. G. Schubert, Zurich 1994. 
Hindemith P., Johann Sebastian Bach. Ein verpflichtendes Erbe, Frankfurt 1957.

Hindemith P., Komponist in seiner Welt. Weiten und Grenzen, Zurich 1959.

Hindemith P., Musik und Musiker in alter und neuer Zeit, [in:] idem, Aufsätze, Vorträge, Reden, ed. G. Schubert, Zurich 1994.

Hindemith P., Unterweisung im Tonsatz, vol. 1, Theoretischer Teil. Erweiterte Auflage, Mainz 1940.

Hindemith P., Über die Viola d'amore, [in:] Aufsätze, Vorträge, Reden, ed. G. Schubert, Zurich 1994.

Jarociński S., Z dziejów myśli o muzyce XX wieku. Theodor Wiesengrund Adorno, "Muzyka"1971, No. 4.

Jarzębska A., Spór o piękno muzyki. Wprowadzenie do kultury muzycznej XX wieku, Wrocław 2004.

Piotrowska M., Neoklasycyzm w muzyce XX wieku, Warszawa 1982.

Pociej B., Co się stało z muzyka w naszym stuleciu?, "Ethos” 1997, No. 4. Schubert G., Paul Hindemith, Hamburg 1981. 